See discussions, stats, and author profiles for this publication at: https://www.researchgate.net/publication/341448538

\title{
View points COVID-19 AND VEGAN DIET?
}

Preprint $\cdot$ March 2020

DOI: $10.13140 / R G .2 \cdot 2 \cdot 20312.11529$

CITATIONS

1 author:

Elham Alshammari

Princess Nora bint Abdul Rahman University

44 PUBLICATIONS 46 CITATIONS

SEE PROFILE

Some of the authors of this publication are also working on these related projects:

Pharmacy awareness project View project
READS

1,640 
View points

\section{COVID-19 AND VEGAN DIET?}

\section{Elham Alshammari}

\section{Department of Pharmacy Practice, College of Pharmacy, Princess Nourah bint}

\section{Abdulrahman University, Riyadh, Saudi Arabia \\ *Correspondence: ejalshammari@pnu.edu.sa}

On 30 January 2020 the outbreak of coronavirus COVID-19 was declared a public health emergency of international concern. ${ }^{[1]}$ Researchers are now in the process of investigating, and perhaps the emphasis should be on the actual cases and their eating patterns. Vegetarians have low viral disease rates. ${ }^{[2]}$ Quick scan of the COVID-19 worldwide statistic showed least infected cases in countries ${ }^{[3]}$ considered to be on vegan diet for religious or animal rights activists' purposes. The dietary habits of those who are infected with the virus need to be examined and documented. The vegan diet poses many risks, but the long-term health of vegetarians tends to be generally good and may be greater than that of equivalent omnivores for some diseases and medical conditions. ${ }^{[4]}$ On the other hand, red meat provides a rich source of protein and essential nutrients of high biological value, some of which are more bioavailable than in alternative foods.

[5] One of Prophet Muhammad's Islamic laws, peace and blessings be upon him, he said, "The son of Adam cannot fill a vessel worse than his stomach, as it is enough for him to take a few bites to straighten his back. If he cannot do it, then he may fill it with a third of his food, a third of his drink, and a third of his breath." ${ }^{[6]}$ Saying with this law, is it balanced diet? Intermittent fasting? Who knows what? It is worth asking.

\section{References}

1- World Health Organization. (2019). Rolling updates on coronavirus disease (COVID19). Available: https://www.who.int/emergencies/diseases/novel-coronavirus-2019/eventsas-they-happen. Last accessed 6th Mar 2020.

2- Rashmi Sharma. (2016). Vegetarian diet and their effect on viral diseases. Available: https://www.longdom.org/conference-abstracts-files/1948-5964.C1.034-009.pdf. Last accessed 6th Mar 2020.

3- Worlometer. (2020). Confirmed Cases and Deaths by Country, Territory, or Conveyance. Available: https://www.worldometers.info/coronavirus/\#countries. Last accessed 6th Mar 2020.

4- Appleby, P. N. and Key, T. J. (2016). The long-term health of vegetarians and vegans. Proceedings of the Nutrition Society. Cambridge University Press, 75(3), pp. 287293. doi: 10.1017/S0029665115004334. 
View points

5- Wyness, L. (2016). The role of red meat in the diet: nutrition and health benefits.

Proceedings of the Nutrition Society. Cambridge University Press, 75(3), pp. 227-232. doi: $10.1017 /$ S0029665115004267.

6- Daily Hadith Online. (2015). Hadith on Eating: Filling stomach a third for food, drink, air. Available: https://abuaminaelias.com/dailyhadithonline/2012/09/21/eating-third-fooddrink-air/. Last accessed 6th Mar 2020. 